\title{
On the Unprotected State of British Commerce at Sea
}

\author{
Lieutenant W. C. Crutchley R.N. Reserve
}

To cite this article: Lieutenant W. C. Crutchley R.N. Reserve (1889) On the Unprotected State of British Commerce at Sea, Royal United Services Institution. Journal, 33:148, 625-651, DOI: 10.1080/03071848909416506

To link to this article: http://dx.doi.org/10.1080/03071848909416506

$$
\text { Published online: } 11 \text { Sep } 2009 .
$$

Submit your article to this journal $\lceil\pi$

Џ Article views: 3

Q View related articles $\longleftarrow$ 
Fridas, April 12, 1889.

Captaix Sir JOHN C. R. COLOMB, K.C.M.G., M.P., Member of Council, in the Chair.

\section{ON THE UNPROTFCTED STATE OF BRITISH COMMERCE AT SEA.}

By Lieatenant W. C. Crutculer, R.N. Reserve.

Ir is some years since I first had the honour of rending a paper in this theatre, but the time which has passed since then has merely strengthened $m y$ convictions that the sabject-matter then dealt with is of great and absolnte importance to Great Britain generally. I lave watched with the greatest interest and pleasure the steps which hare already becu taken for the better security of our rast properties at sea, and tho only way in which one can find fault is, that they do not go far enough, and so I say, "Yet for a man may fail in duty twice, and the third time may prosper."

I do not know that the foregoing words are quite appropriate, but they come to iny mind as a reason for another effort to bring this great subject forward. With all Europe an armed camp, with Britain tho arowedly first cnemy at which ambitious Powers would strike, with the knowledge that failure on our part to protect ourselves would be irreparable, we still continue to displaj a singalar disregard to the claims which our enormous properties at sea undoubtedly have to be protected from the hands of coictous neighbours, and this disregard I fecl conrinced is solely becauso the majority of people have never grasped the meaning or magnitude of the question at issuc.

I think that my remarks may be classed under four heads-

1st. The necessity" of protection of our trade at sea at the commencement of war.

2nd. What would probably happen under existing circumstances on the particular roates touched upon.

$3 \mathrm{rd}$. 'llhe necessity of an organization of mail steamers to assist the first point mentioned, and the urgent necessity of arming them.

4th. Sketch of a plan of convoy for the Cape route, and some remarks on the rital need of such depots as the Falkland Islands and Sierra Lconc.

In approaching this subject, I must say that I do so with great diffidence. I should scarcely care to be considered an alarmist; but 
all the discussions which hare taken place lately on the subject of our Nary hare, as far as I have scen, been solely coufined to the ability of our men-of-war to meet successfnlly those of our possible antagonists; the protection of the greater part of the cornmerce of the world has not been touched upon at all, and it is in the hope of assisting to prevent the temporary (it may bo) stoppage of this commerce that I lave provoked the discussion that I hope will follow the reading of this paper. I do not think that landsmen quite realizo the haroc that it is possible to work amongst unprepared merchantmen on the sudden ontbreak of war, and I scarcely think that the powers that be care to grasp tho question. We have arrived at a period of history when the struggle for wealth, both individual and national, assumes rast dimensions. It is all very well for statesmen; living in their ideal world of hatred of war and injustice, to say that war canuot be permitted on the score of its unreason and brutality. Even the most modern history shows us that a firm and prepared front is the best anfeguard for peace and its blessings; and the outspoken words of a celebrated Frenchman, that twenty fast and wellfound craizers would ruin the commerce of Britain, is approaching more closely to tho truth than is at all desirable from tho British point of ries. The fact remains that, at the time of the last war senre, there was an atter absence of any information amongst merchantsteamers leaving port about that time, as to what was to bo done in the erent of war, and, as at present $I$ do not know that we are anj further adranced-presumptuous though it may appear on my part to adrance theories on the matter in the face of the great authority that recontly stated that it was impossible to arrange eren a system of signalling between men-of-war and merchantmen-I must, with erery respect, confess $\mathrm{my}$ inability to see where the difficulty lies, and I think it quite within the range of practical measures to ensure a far greator amount of safety for, or to, our steam tonnage in war-timo than it is now in posscssion of.

Without going into absolntely accurate figures, my statisties, as follow's, are taken from the "Statistical Abstract for the United Kingdom for 1887." By that authority I sce that the import of grain into the United Kingdom is valued at over $48,000,000 l$, that rarious other articles of food, such as meats, both fresh and preserred, cheese, potatoes, and tea, como to another $31,000,000 l$. per annum. That this is a startling fact I think will be admitted when we know that England is victualled for three months at the lougest, and when we consider the fair probability of the stoppage of our food supply at the commencement of a maritime war; what rould this mean to the enormous masses of the norking class, who find extreme difficulty even now in keeping soul and body together? 'To comparo small things with great, what happens if snow delays the ordinary traffic to the metropolis for theo days? And what would happen were our grain supply to be cut off even for one month? 'There rould be such internal misery and dissension that one might well shrink from the contemplation of the hideous pictures that ordinary foresight could freely paint. We know the excesses to which a French mol 
can run, we lack the experience fortunately of the capabilities of an Finglish one, yet recent 'I'rafalgar Squaro riots show what excesses can be ran to, eren under an exceptionally strong government, and it requires no great stretch of imagination to foresee the possibilit. eren in our oirn time of a repetitiou of the Commune should the food supply of England once really fall short of the amount necessary to feed the masses of the population as they are fed to-day.

I have found it useful of late senrs, when thinking orer cortain things connected with lifo on boaryl ship, to say to myself, "What is the worst combination of circumstances that can possibly happen?" and, having made up my mind what the worst could be, I hare added $a n$ to represent the unknown, and then prepared to the best of $m y$ ability for what was to come. It is a plan that I think has its merits, for although on suggesting that a certain contingency might arise, one is usually met with the answer that it is rery unlikely, the fact remains that it is possible, and so I contend should this same question we are now discussing be looked at.

I spoko just now of a fnir probability of the stoppage of our grain suppls. Is there a fair probability?

Whaterer tho relative strength of our Nary may be when compared with that of France, I will assume for tho sako of fair argument that it is equal to the combined warships of France and Russia. Not all our Naval experts, perhaps, rould admit that it is 8o. There can bo few more difficalt questions than the relative theoretical strength of navies or warships, bat that is not the point. just now. Were we at war with France and Russia cornbined, what remains to protect our commerce against the dozens of fast raiders that wonld bo turned out in all directions to capturo our merchantmen? The "Alabama" was no question of a warship. She was no better able to fight a battlo than a very second-rate merchant steamer could now, and she sunk in her first engagement; but sho was a raider that destroyed the commerce of America afloat, and drove its trade to foreign flags in such a manner that eren that rast selfsupporting nation has been unable to regain its place on the sca.

That happened at a time when commerce was small compared with what it is at present, and when specd at sea was not anything ncar its later derelopments. Theso two factors taken together mean an increased rate of destruction in war-time, and the entire captures of the "Alabama" could be easily cclipsed in one week now by one fast and very moderately armed merchant cruizer. This is no question of speculation. Wo know exactly in which direction our enemy would strike at us, and it would be at our weakest and most rulnerable possession-our shipping. I hear it frequently said that in the crent of war our ships are to be transferred to a neatral flag. What is intended by that phraso I fail to understand; scarcely any collection of neatral flags could take orer our ships and work them; and even supposing such a plan were in rcadiness, would an enemy of ours respect such transfer? I think not, and even were they to respect the ships, France recently declared rice contraband of war, and so eren the neutral flag would be unable to conlinue our grain supply 
under.those conditions. But, assuming that this transfer were possible; what is the result? 'Trade follows the flag, and our ships under a neutral fiag would mean simply. ruin to England. I cannot conceive anyone calmly contemplating the trarisfer of our. ships to foreigners. Our. ships sailed by men of the nation under.whose flag they sail; our seamen idle and carning nothing, the shipowners with their realized capital laid ap and unable to use it (supposing it were realized), and our one big trade gone. I confess to havo no liking for tho picture. Our stronghold is the sea. . Wo have claimed the .mastery of salt water for centaries, and it would be a poor climax now to seck the cover of a neutral flag, and confess our inability to protect our own. Here I cannot resist quoting from a speech of Sir. C. W. Wilson, at Bath, 1888, before the Britisl Association:-

"I may add here that if there is ono point clearer than another in the history of commerce, it is this - that when a State cannot effectually protect its carrying trade in time of war, that traile passes from it ast docs not return. If England is crer found wanting in tho power. to defend her carrying trade, her fate will only too sarely, and I might also say justly, bo that of $\nabla$ enice, Spain,. Portugal, and Holland."

... It may be said that the subsidized steamers on the Admiralty List will be quito. equal to this work, I mean that of looking after an epcmy's raiders. :Doubtless, they would bo if there wero.enough of them fairly started with their enems in riew; but this same fair start requires greater consideration than it has yet received.

$\therefore$ They could not satisfactorily be taken from their own routes. The want of them would bo. too surely felt, and the need of: them too vital, as I shall endeavour to show later on-and to sam up this part of my argumeut in a few xords, there is the commerce of England at sea practically undefended : liostile armed merchantmen hastily and perhaps indifferently armed, but flying a Goremment flag, would tako our ressels at a disidrantage (especially Russian cruizers expressly intended for this purpose), and the : result would be the disappearance of the British flag as the carrier of the world, to bo replaced by the stars and stripes, and. Teutonic and Scandinarian emblems.

The foregoing remarks hare; I bope, pointed out the necessity for protecting trade at sea on the commencement of hostilities, and the absence of means for doing so at present. There is our Nary; tho largest and best slcarnship company in tho world, but still too small for the work it has to do, and so must either take in more capital, or amalgamate with somcone that can help the work in hand. Perhaps both courses might be adopted with advantage.

i The question as to . what would probably happen on all the trade routes of the world, under existing circumstances on the outbreak of war, is far too large to be dealt: with on. such an occasion as the present. : The ocean trade routes of the world cannot bo glanced at ercn, within the limits of this.paper. The subject also requires a greater amount of detailed knowledge than I can pretend to bring to it. I therefore propose to confine my remarks to the trade that 
would probably spring into existence betwoen the two great Capes and the Channcl. But first, I should say a few words on tho probable method of clealing with captured ressels-it is a largo tield for speculation.

In the late Naral Manourres it liappened that sereral merchantnen: were brought to by cruizers, and captured and released-now what does this mean?. It means simply that vessels employed in their peaceful arocations, in utter ignoranco of even sham warfare, were stopped by a shot being fircd across their bows. : So far, the procecdiugs might have bcen the saue had it been reality; but in place of releasing the captirc to pursuo her royage with a mark on her to show sho had been taken, what rould have happened in actual warfare? IVhat would an enemy hare done with tho captured vessel? - Let us assume her to havo been a P. and O: ship with a large crew and a number of passengers: I will supposo her to hire a crew of 120 mon and 200 passengers, and that four days' fair steaming would take her into an enemy's port, cither one side or the other.

In all the discnosions which hare cropped up on this subject of merchant shipping in war-time, the Dcclaration of Paris has always formed an important item of the debate. By many it is looked upon as an unmitigated blessing bestowed on Great Britain-by others it is regarded as a great mistake on our part, and ono that sliould bo repudiated without delay. I cannot say that I am of this latter opinion -this treaty, in spito of somo alleged informalitics, was undoubtedly cntered into in fartherance of the interests of modern cirilization-it was subscribed to by the Plenipotentiaries of the majority of the Great Powers of the would. But I cannot beliere that it wits the intention on the part of the representatire of Great Britain to place that Power in in far morse position than its neighbours-I say far worse, bccause with a frontier which, for as, is bounded by the farthest shore of the sea, our outposts by tho generally understood meining of that docnment are to be simply unarmed patrols - that haring the ejes to see and the strength to act, they are to be deprived of all or any wenns of defence, that strong and speedy though thes may be, they aro to have no refuge, sare in flight from tho meanest and least powerful of an encmy's ressels, and in proportion to onr grenter number is the power of a possible enemy to inflict damage which could not be returned by vis in similar coin. The worst part of this is, that we should be anable to profit by our national trait of taking the first beating kindly-that meaning that we should cease to bo the market of the world, and thereforo hopelessly ruined. My reason for these latter remarks will be more apparent as I procecd.

Now the Powers that can fit out priratecrs are thrce, riz., Spain, Mrexico, and the. United States, and it would be difficult to imagine less likely adversaries. Prirateers having to take their prizes into port for in legal decision as to right of capturc, and tho: Great Powers having forfeited the right, or rather haring given it up roluntarily to fit out prirateers, it would be necessary that the vessels preying upon our commerce should possess the licence to sink, burn, or destroy: 
and this power is only posicssed by a man-of-war or a ressel fitted out by the Stato with that end in ricw.

There are three courses open with a captured liner. To send her into port with a prizo cres.

To take the people out of her and sink her, or to sink her as she is.

In the first case, what sort of a prize crew would be required ? It would need Officers, engineers, and men, and cven if every man of tho prize crew had a belt full of pistols, to compel the original crew of the ship to work, when away from the guns of the captor they could not do it, unless in fairly strong force, say fifty all told, and that nawber would be a serious drain upon any slip's company. Could less do it? Knowing something about a ship's engine-room, I doubt it.

$\Lambda$ torpedo-boat would be a far better escort, and if the ship were unarmed, would bo the best thing.

If again it were proposed to destroy the capture, what could he done with the passengers and crew, iucluding, perhaps, women and children? There are three courses.open. To haro in readiness a tender to receivo them, equally as fast as the captor. To take them on board the criptor, a course open to many objections one need not par. ticularize, or to place them in their own ship's boats, if there are hoats enough, and turn them adrift. A great objection to all these methods Fould be the loss of time taken up in pursuing any one of these courses.

In Mrr. Kinglake's History of the Crimean War there is a rery interesting chapter relating to the Coup d'Etat of Napolcon the Third. In it ho enters exhnustirely on the different kinds of slaughter of non-combatants, as compared with the shooting in Paris on that occasion. I do not find in it any trace of a case similar to the latter one, and it might, perhaps, be fair to nssume that to a humaue captor, a passenger ship would be a sort of white elephant, if captured when far away from a home port; something may, perhaps, be said on this subject as against arming them, and thus rendering them cum. batants. But I am afraid that modern warfare will probably celipse in its rigour anything the world has yet seen, and in the endeavonr of an enemy to damage the commerce of England, no consideration of ruth or humanity wonld be entered into. I hope I may be and am mistaken, but I think that ships would be sunk promiscuously whenever and wherever they were found, and that this would be carried out eren by humane Officers as necessitated by the needs of war.

I presnme that no probable adrersary of ours could fit privatecrs without our being also ablo to lo so, so that if it comes to arming morchantmen to do daty as men-of-war, we ought to have the advantage.

With the Suez Canal blocked, which is onls a fair risk to take into account, and is moreorer a probable contingency, and certainly a point for which an enemy would strire, the trade from the Fast would naturally be diverted to the Cape routes, not even altogether because of the stoppage of the Canal, for it is a question whether fast ressels would not rather trust themselves to the open sea if they wero 
sure of their coal suppls, in preference to narrow waterwass like the Red Sea and Mediterrancan, unless they were well convoyed. Now we know that men-of-war, even if they could be spared from near home, do not caro to keep tho ser long, and steam long distances. It is nearly 6,000 miles to the Cape of Good Hope, and how long would it take to get the ressels out there that would bo required on the ontbreak of war to protect the trade that rould centre in Table Bay: if there were warnext week, what armed slips are there to protect it? The "Raleigh" and the "Penelope," witha few smaller cruizers. I don't think that the weather on the Agulhas bank would suit any of them very long, and I should say that three vessels of largo coak capacity with Réunion o1 some port in Madagascar for a depót or coaling station, could, if sent ont by an enemy, hare a rery pretty hunting ground for their nudisturbed amusement for some considerablo time. I have the French Messageries mail steamers in my mind as I writc, and nothing on the Cape station at present could catch them at sea; so far as men-of-war are concerned, there would be little trouble there on the sulject of passengers, and Jack adrift in an open boat would excito no great amount of sympathy; ho is used to drowniner.

While on this matter concerning the Cape of Good Hope, and the uatural conrergence of trado to it in war-time, I should point out that from 5,000 to 6,000 tons of coal is the usnal stock in tho placothe import was 110,000 tons last year, and that only sufliced for the ordinars traftic, so that unless the coal-fields of Natal derclop largely, this item will prove a serious source of trouble. The coal import there is largely dono by Italian sailing vessels, but as thero is little doubt as to coal being contraband of war, I don't see that it would help us much-it would be curious to see Table Bay full of steamers waiting for conl: true, they would be in comparative safety, bat what about the people at homo who are waiting for the supplies thus detained?

Now take the Cape Horn routo and the trade by steamers through tho Straits of Magellan : one important item would be the grain from the Pacific ports, the value of which alone amounts to more than $4,000,000 l$. per annum, and is now conreyed to England principally by sailing ressels, but which wuuld, on the outbreak of hostilities, hare to bo carried by steamers. With the French Messageries steamers running to Rio do Janeiro, by far the fastest ressels on tho routc, and ready as they doubtless would be on the outbreak of war to take the initiative, what aro the mcans at hand to catch them or hinder them from picking up our sailing vessels and steamers in all directions? The "Cleopatra" cannot be everywhere, and after the "Swallow" is mentioned, the rest of the south-cast const squadron might as well be in Portsmouth Dockyard for anything they conld do to protect our ships in that direction, and if they cannot do so, where are the ressels to be sent in a hurry to take up that duty on the ontbreak of war, and generally to protect this ronte? It must bo borne in mind that with the Sucz Canal blocked, Cape Horn is on the road home for steamers from Australia as woll as from Now Zealand, and 
that therefore the traffic on this route would increase cnormously also that both steam and sail routes from the Hoin to the Lino are not far from one another, which fact is all in favour of tho enemy-aloo that the remarks as to scarcity of coal supply at the Cape, should tho trade increase suddenly, apply with additional force to this ronte The Falkland Islands are our only depot, tho stock of coal there is not worth speaking of, and it is a long distance to steam from Australia to Buenos $A$ fres or Rio. I do not see that tho lialf-dozen fast cruizers now in reserre would be too many to patrol this route, but I cannot resist the idea that they would find their work fully cut out a great deal nearer hoinc, and hero I quote words used by Admiral Colomb in this theatro:-

"Is it not reasonable to, assume that the 900 steamers in Frapce thrown out of ordinary commercial . work. by the war would bo largely employed for raiding purposes?" Ho also, mentions the 1,800 or 1,900 ressels leaving and entering; tho. British ports daily, and, funlly, "it seems as if, nnless thero are armed ships on the spot whereter shipping is thickest, a single raider in the short time at his disposal might do enormous damage.".

I think I hare shown that our coinuerce, as totally distinct from the question of fighting between fleets of battle-ships and the defence of the country itself, is not satisfactorily protected.. I should say that the grain trade alone, which would be diverted to these two routes in the erent of the blocking of the. Suez Canal, rrould be to the value of $10,000,000 l$. per annum at lenst. I think it will bo generally admitted that we should, nuder existing conditions, sustain our heaviest losses during the first iwo montlis of -war, beforo tho ressels we rely upon to run down the enems's raiders aro cuabled to arrive at their. stations, and this being so, does it not show the necessity of some vessels on the spot being put into some siath stato of fitness as sliall enalile them to take part in the forning of convoys and the protection of them to a certain extent, until thes can arriyo at, what may bo termed tho fighting ground of battle-ships ? The mere fact of any merchant steamers being sclected to carry guns on an cmergency is quite enough for my argument. What one can do another can within moderate limits. By this I mean that the difference betwoen the subsidized ressels and an ordinary. first-class wail steamer is not such as to' ritiate my argument; and cren . if inferior ressels were used we could afford to lose ship for ship far, better than any of our neighbours.

$\therefore$ If the control of the highways of the sca is ony heritage as rye fondly inagine, and we are to retain it, it will not be done by a mere comparative superiority of strength, it will hare to be by a decided and decisire one, and unless the fleet of 100 cruizers asked for by Adminal Iloriby is to bo called into existence, in wo other way can it be done than by securing: the serrices of numbers of mercliant stearners; :scarcely any effort that I could imagine would do so satis: factorily on the outbreak of war with an encms bnocking at inang of our liundred gates. With our Nary admittedly far too small for the work it bas to:do, is it not worth while now to commence and seo. 
what can be done in the way of organization and arming of some of the most suitable steamers on the routes of which I have been speak: ing? It is so easy to do most things if one only las time, but the want of it in this case would be simply disastrous; time meaning leaving the victualling of Fngland to take its chance. Diplomacy lias its das, and that day is usually a long one, giving an enemy erery opportunity to make sure of our intentions and to be ready ais soon as ourselres to endearour to strike the first blow. What better opportunity, could there bo than the present to institute these reforms necessary for our safety, and which if taken in hand when any relations wero strained with a, foreign Power wonld undoubtedly make matters worse, and perkaps precipitate events which might bavo been avoided and would perhaps be regretted?

It is now a matter of history that at the time of the last Russian war-scare their cruizers were encountered in the most unexpected places, and the inference is that they will be still bettei prepared when the inevitable occasion comes. : What our preparations were it is needless to discuss; but I presumo it is well bnowin that wo were anxious to buy and pay double cost price for at least one fast cruizer that could both keep the sea and tight. Now, if it was considered necessary then to incest balf a million of money in one solitary. instauce, vould it not be rrorth while to invest a moicty of that sim in putting somo of our own resscls into such a state as should in a great measure obyinte the necessity for such a prospectivo outlay?

Before proceeding further in this matter I should like to stato that I : do not propose or contemplate a conroy of armed merchintmen without a man-of-war to take charge of them. I should not proposo a collection of British ships to afford target practice for an enemy่, which might liappon if there wero no ship present capablo of meeting a man-of-war, and prerenting a game of long borls, where the odds wonld be all against the ressel showing the biggest side. And here I would like to suggest, in the most unobtrusire minner possible, that the length of the cruizers nostly. built now for the protection of our commerco is a fatal bar to their efficiency. I should rather say their want of length, for notling under 350 fect is fit for decp-sea speed.

Thero was a ressel built sone little time sinco by Isord Armstrong, who is reported to hare said that sho was more than a match for a flect of armed merchintrien; of course sucli an nuthority is a difficult onc for me to question, bat I thiuk a little may be said on the other side. Steam is a great leveller of odds at sea, and the stem of a merchant steamer is almost as formidable as that of a man-of-war; thero is tho force that, properly applicd, is capable of sinking any yescel not strong enough to resist it, and I canuot dismiss tho idea that a convoy of merchantion is not to be handled with the impunity which is commonly inagincd. Thero are certain casy formations which could be maintained with no risk to themselres, even by vessels not accustomed to keep station, that would put eren an "Esmeralda" in a fix if she rentured amongst them, presupposing there wero any shred of organization, which there undoulstedls would be if they crer found themselres in such a position. 'There is no truer sajing, and it 
has been applied very closely to naval affairs, than that "History repeate itself," and if a flect of merchantmen has succeeded in beating off an enemy before, there is at least the inference that it may do so again; bat in tho notable instance in which it did so, the ships were well organized and disciplined, and this would necessarily be a sine quo non now, and herein lies the great gist of the matter.

Now, if it is said that it is of no avail trying to organize merchant shipping for its own defence or for a certain purpose not immediately connected with its own pursuits, look at the rast strides the $P$. and 0 . Company has made lately towards manuing and officering its shipo with Rescrve men. I say rast, because small though the actual numbers of the men are, the bare fact of the expression of the wish of the directors of that company has becn enough to foster the scheme amongst their employés. How or why that wish came to be expressed is a matter unknown to outsiders, but it is reasonable to supposo that the directors of that company did not consider it would bo detrimental to their interest as the first mail service of England. Undoubtedly, many ressels of that fleet, other than those on the subsidized list, would hare to play an important part in that quarter of the world to which they trade, should war occur. The interests there would be far too valuable to sacrifice by taking the vessels off the route. It wonld be too fatal a mistake to part with one item eren of our trade in wartime that wo conld possibly retain. And so to return to the Capo route as tho one immedintely under discussion, I shonld say that if considerable trouble had been expended on the preparation of vessels to look after themselves and perform some of the work necessars in war-time betreen the Cape of Good Hope and England, none better could be selected than those of the Union SS. Company of Southampton. Having sailed in them for many years I am fairly justified in expressing an opinion on the matter. What the directors of that company would say to my suggestion as to the use to which it is possible to put their fleet I know not, but I know that if the expression of some wish at headquarters has been enough to influence the P. and 0 . Company, I do not imagine for ono moment that the Union Company would be less willing to more towards their own interests. Were they once convinced that such a course was advisable, no better ships could be selceted for the trial of any now plan. They are extremely hands ressels, can arerage about 14 knots per hour, and sailing from Southampton offer exceptiounl advautages in farour of the end I hare in view. I beliere it possible in such a port as Southnmpton to practically retain ships' companies for years and jears together, and I instance this particular company for the reason that it and the Castle Line are at work on the route ander consideration. And having suggested the possibility of such use of mail steamers, it somewhat rightly dorolres on me to show the practicability of the scheme.

Here, again, comes in history as a precedent: in all our great naval struggles, notably in tho caso of the Spanish Armada, each port sent out its batch of ships under their own separate organization, and yet capable of working towneds one common end. 
This matter of the rorking of groups of merchant or mail stcamers is capable of easy solution; any mau of ordiuary ability appointed to work a group of ships to carry out a well-planued scheme could do it with little difficulty if properly instructed as to the broad ontlines of the plan; the appointment would be little differcint from that of the mail officer or agent of the pist. He would know accurately the morements and routes of his own ressels, and where they coincided with those of other lines; and if Marino Superintendents of Jarge stermship companies receire honorary commissions in the Naval Reserre they. would doubtless also bo pleased to perform any dutics which might fairls go with their honorary rank. I have not the lenst hesitation in saying that tho majority of these gentlemen would be the ones to work the plans satisfactorily. Eren a small subsidy to tho companies concerned would produce the ends desired in the time nsually taken by merchantmen to carn their mones, and that is tho shortest possible. I say a subsidy to lines that aro not in reccipt of a retuiner for their ressels, for it would not be reasonable to expect any company to work, eren for the cornmon weal, if they were not paid rersonably for their efforts ; it might also well be a matter to be considered in the placing of mail contracts.

I have spoken of the subsidized vessels at present on the Admiralty List being required on their own routes; tho North American trado would ill spare its fastest and best ressels under tho conditions of modern warfare, still less could ressels on the Australasian lines be taken from their ordinary traffic; the stoppago of trade with our Colonies would be a rast misfortune to contemplate, the exports of food alone from Australia anounting to $3,000,000 l$. in 1886 ; aud part of the enormons grain supplies we receire from North Americn wonld surely find its way to England by the fastest ressels procurable.

There is no armament abroad worth the name of such to put into any vessels that may be required on au cmergency: a spasmodic attempt was made six years ago to meet the want, with little result, save the water carriage of many obsolete weapons. I do not, however, say much on this sabject, as armaments hare changed very considerably since I first made any remarks on it, and wo must move with tho times; but why not try the experiment of putting a decent armament of quick-firing guns into the fleet of ressels I bave mentioned? With depots for ammunition on the route, the matter would be capable of a great facility of rorking, aild a fleet of well-disciplined, sound, fast, and useful ressels is ready, so to spenk, constantly.

The question of the magazine is, I imagine, the most serions one by far; no large supply of ammunition could be carried orring to the difficuity of port regulations, dock rules, \&c., but quick-firing ammunition is widely different from the old system of cartridges and not nearly so dangerous, so that I do not look upon the difficulty as insurmountable -the guns themselres are no obstacle, the great difference of weight betseen modern and old-fashioned guns having removed one great objection; should anj such scheme as this get a trial and prore a failure, the expense wonld not bo worthy of consideration as compared with the great interests at stake, though I do not believe that in the 
rcssels I have indicated failure would be at all probable, and what can bo done in ono service can be done in another if it be proved wortl while. There has been a falling off lately in the numbers of tho First Class Reserve men; there used to be an idea that reserve men were not popular with shipowners, in consequence of their liability to be called npon for serrice; that is entirely exploded, both in tho case of Officers and men, but if this force be worth boing taken care of, no better system of oucouragement could be adopted than by so arranging matkers that the leading lines of steaners should seek to obtain them. I am well aware that notbing is likely to succeed in this commercial age that does not give a fair prospect of gain or adrantage to someone concerned in the business in hand; this present matter is an extremely big one, and the bearing of it on the merchant service of lingland is not seen by all. By no amount of legislation wonld it be possible to produce the same results from a Board of 'Irade point of riew, as would this scherne wero it given a fair trial; it would mean a revision of the oficering of the mercantile marine, it would pat an end to the vers unsatisfactory discussions ihat wage about superior certificates, and it wonld produce a class of men that could fight their shipg as well as work cargo. In other words, it would mean that the Naral Reserre, in place of being a force costing little and doing a proportionate amount of work for value received, would become to all intents and purposes a reality, it would haro arns to fight with, and a colerence that at present it does not possess.

The Voluntcers of England are mach exercised in their minds now as to their efficience, should they be called upon to take the field; they want a bigger capitation grant, great coats, rile-ranges, and many other things that thes will donbtless get. But is the danger of an invasion of England to be spoken of in the same day with the extreme peril our commerce is in at sea? Yet this force, the Naval lieserve, which I suppose is intended to correspond to the militia, has, from its very beginning, "been kicked loose and billeted nowhere," and that this is so is, I fecl con rinced, becanse pcople will not look at things from a logical point of riew. If wo lose our trade and the command of the sen, the fact of an invasion, more or less, will little influence the destinies of England, and all the armed merchantmen we could master wonld little arail us without a coiresponding increase of our men-ofwar on the routes here under discussion, to excrcise the superior controlling power and provide angthing like adequate protection to the enorinous wealth at sea.

In the accompanying map it will be seen that the two routes of the conroys from east and west converge at Sierra Leone, and that cighteen vessels (mon-of-war) are required to form conroys, irrespective of armed merchantmen. Of these eighteen, three may be termed station ships, and one should be somewhat after the style of the "Orlando," to remain on that part of the route between Pernambuco and Sierra Leone. I think it would be far better were the same vessels to remain on their own part of the route, which may be dirided on the cast const of Sonth America into four portions. I lave assumed a speed of 12 knots for the conroy thronghont, and my renson for 
JoronaliRUSInstikution

Vol $\mathrm{XXXWH}$.

Hate 10

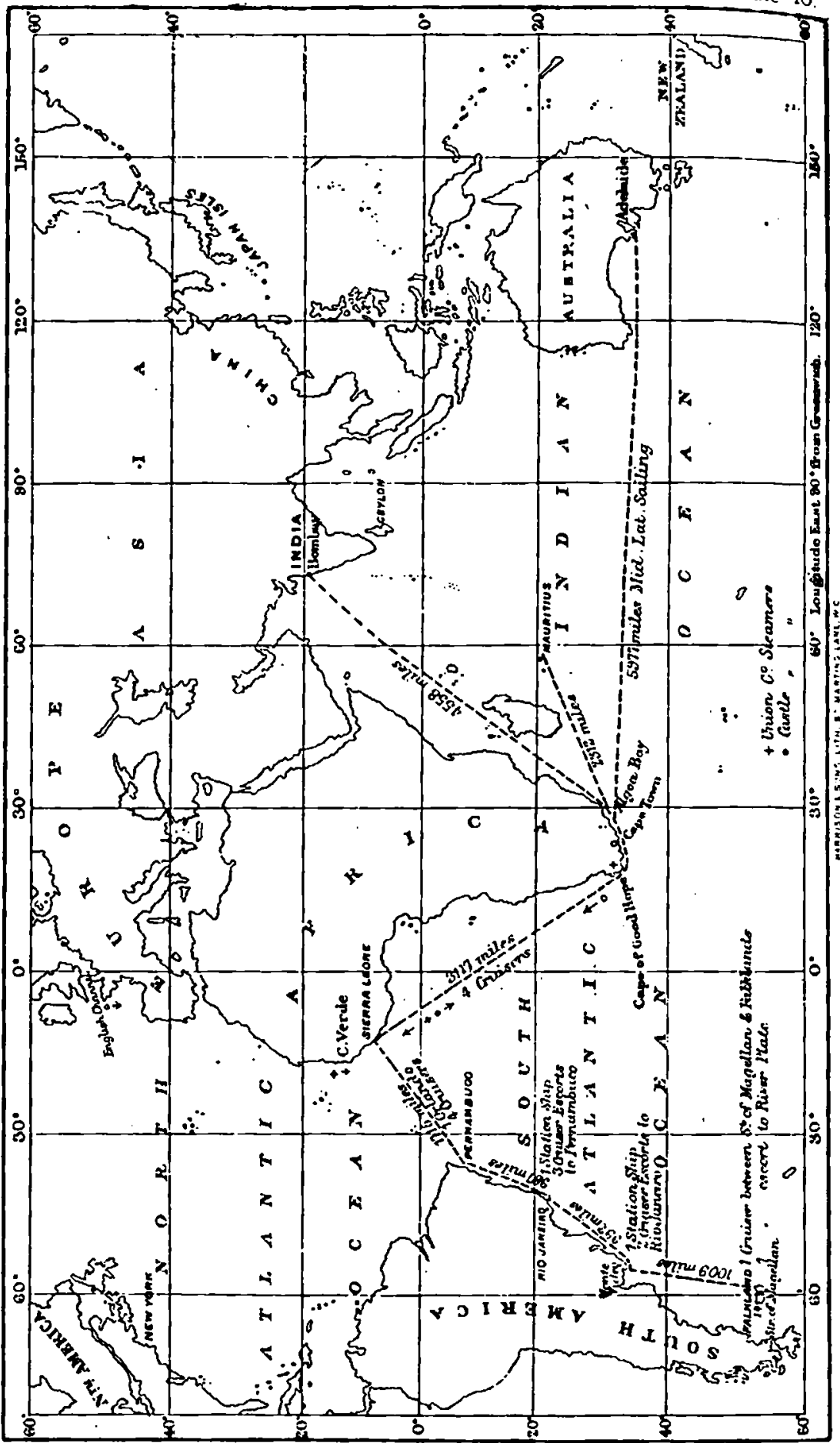


casing that the mien-of-war should remain on their own position of the routo is, that they, not being accustomed to steaming long distances, could not, without occasional stoppages, do the work which is the eversday business of the merchant steamer.

The patrols would be-

From the Falklands to the Plate,

The Plato to Rio de Janeiro,

Rio to Pernambuco,

P'ernambuco to Sicrra Icone.

Sierra Leone would bo the rendezrous also for the Cape of Good Irope conroy, and from that port into Channel thes would, of course, require far more careful watching than they hare hitherto had. I do not express any opinion on that subject, but I scarcely think that any naral Officer present will say that $I$ haro taken an exaggerated riew of the needs of these two routes for men-of-war only; eren as it is, there are numberless difficulties to bo encountered, one of the principal of which would be the coaling of the men-of-war. On the Cape of Good Hope routo the convoy would be formed in Table Bay, and there, if it were to be had, the ressels would take coal enongh to carry them to Sierra Icone. If privato enterprise or Gorernment forethought had not foreseen the want of coal at that port, theire they would remain until the necessary suppis was forthcorning; bat with tho southcast coast of America it is different. Between the Falkland Islands and British Guiana, which, for all practical purposes, may be taken to mean the West Indies, we hare no port; and whether the Argentine Republic and Brizil would consent to our using their ports as coaling stations for our men-of-war, is a question that may perhaps liave to be argued after the crent; but if this were so, it would point out that the coaling of men-of-war would havo to be done at anchorages on the const; or else Rio would hare to be considered a central point, and Sierra Lcone and the Falklnnds considered as finals. I am under the impression that this, the south-cast coast of America, would require a great deal of atiention. At a speed of 12 knots, it is six days from Sierra Lcone to Pernambuco, three more to Rio, three more to Buenos $\Lambda$ Jres, and three moro to the Falklands.

The ships on the South-East Coast Station are the "Flamingo," "Rifleman," "Cleopatra," and "Swallow"; on the Cape and West Coast, "Acorn," "Alecto," "Bramble," "Curaçoa," "Goshawk," "Landrail," "Penelope," "Pheasant," and "Ralcigh"; and I must leare it to experts to say what would be the ralue of these ressels if used for convoys.

When I mas last at the Cape I got the positions of all the mail steamers, and placel them as shown on the man. It was the 4th of January, and I conclnded that if war wore declared on that day, by the end of the month Table Bay would be filling up with ressels stuck for want of coal. I do not know whether it enters into tho present programme of defence to lnok after Sierm Leone and the Falkland Islands, but I do not see how thes can cscape playing a rery prominent part in any future naral war if properly utilized. The French had a big coal depót at Goree jear's ago. I should say it would be a 
very serious thorn in our side if we ever have the misfortune to quarrel with them, and hare no similar depôt in the ricinity, whilst the Falklands are simply of rital importance to ressels coming from $\mathrm{New}$ Zealand and Australia.

I do not know whether my arguments carrs any amount of conviction with them. I am so firmly convinced in my own mind of the accurncy of what I state, that I have not, perbaps, sufficiently cmphasized detail to satisfy all my hearers, but I do hope that the discussion which follows this paper will help to show that the danger that threatens England is not invasion but the destruction of its wealth at ser.

\section{"Statistical Abstract for tme Usited Kisgdon (No. 35), 1S87."} No. 26 (p. 51). Quantities and Values Imported into the United Kingdom.

\begin{tabular}{|c|c|c|c|}
\hline Corn. & 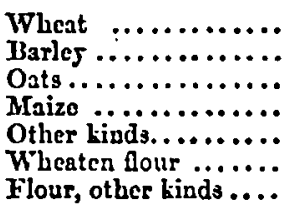 & $\begin{array}{r}55,802,518 \mathrm{cwt} . \\
14,239,566 \quad " \\
14,462,943 \quad " \\
31,167,325 \quad " \\
6,334,360 " \\
18,063,234 " \text { ". } \\
895,961 "\end{array}$ & $\begin{array}{r}\{21,337,918 \\
3,761,497 \\
3,458,320 \\
7,513,272 \\
1,851,863 \\
10,027,851 \\
272,025\end{array}$ \\
\hline & 'Total of corn. & $1.10,965,907 \mathrm{crrt}$. & $848,290,793$ \\
\hline & 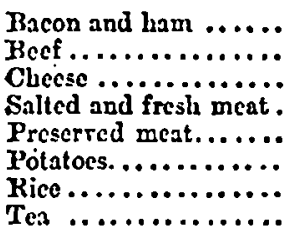 & 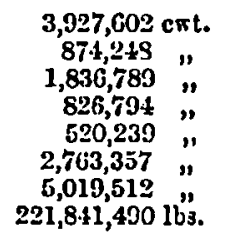 & $\begin{array}{r}\{8,733,776 \\
1,811,237 \\
4,514,352 \\
1,681,116 \\
1,351,769 \\
974,904 \\
1,873,551 \\
0,782,993\end{array}$ \\
\hline & Total & $37,610,031$ & 3,733 \\
\hline
\end{tabular}

No. 30 (pp. 70--71). Quantities of Grain Imported into the $D_{n i t e d}$ Kingdom.

Wheat.

From U.S.L. Pacifie ports... Chilc ............... British India ......... Australasia .......... South Africa, British Posscssion $3 . . . .$. .. Total............. $9,978,202$ ckt.
$2,206,272 "$,
$8,511,512 "$
$1,3 \cdot 17,151 "$
$\frac{40,501}{22,092,633}$ cwt. $\{4,014,039$ 836,529 ; 3,102,96-1 531,243 18,303 $£ S, 501,033$ 


\section{"Asiual Statemext of the Trade of the United Kisadoy yor} YEAl: 1887."

\section{Preserved Meats.}

\begin{tabular}{|c|c|c|}
\hline Australasia........... & $167,101 \mathrm{cwt}$. & $\mathcal{S} 3 S 6,810$ \\
\hline & sh Mrutlon. & \\
\hline $\begin{array}{l}\text { Australia............. } \\
\text { Ner Zealand ........ } \\
\text { Argentine Republic .. }\end{array}$ & $\begin{array}{l}42,4.45 \text { crrt. } \\
395,639 " \\
251,273 "\end{array}$ & $\begin{array}{l}x 77,003 \\
811,203 \\
412,507\end{array}$ \\
\hline Total ............. & 659,350 ewt. & $£ 1,361,413$ \\
\hline & Rice. & \\
\hline 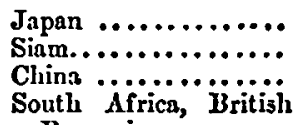 & $\begin{array}{l}167,799 \mathrm{cnt} . \\
39,491 " \\
26,616 "\end{array}$ & $\begin{array}{r}£ 67,611 \\
13,225 \\
13,287\end{array}$ \\
\hline 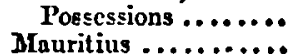 & $\begin{array}{r}2500 \\
10,200 "\end{array}$ & $\begin{array}{r}120 \\
6,325\end{array}$ \\
\hline British East Indics ... & $4,309,278 "$ & $1,506,200$ \\
\hline Total, & $4,502,63 \div 4 \mathrm{crt}$. & $£ 1,606,783$ \\
\hline
\end{tabular}

\section{C'nfice.}

South Africa, British

Posscisions .........

British East Indics ....

Hong Kong... . . . . . . . .

Total
3,0S7 owt. 272,65? ,.

718 ,

$276,497 \mathrm{cwt}$.
$£ 9,817$

$1,178,150$

2,476

$£ 1,190,473$

Admiral Bownex Syirn : $\mathbf{M}$ r. Chairman and gentlemen, $I$ think it is a rery good thing for this Institution and the country also, when a gentleman of Licutenant Crutchley's experience comes here to read a paper on a subject of so much iroportunce as this. We are rers glad also to sce you, Sir, in the chair, for I do not think unyone has done more than you hare to bring this subject before the country. It is admitted that the protection of our commerce demands a large proportion of cruizers, and, I think, all our hearts hare been recently gladdeued by the rery excellent, and, I think I mas say, judicious shipbuilding programme, which lias licen put before tha country by the First Lord of the Almiralty, and which has already practically passed the Ulouse of Conmons. Unless, howerer, we hare our organization complete, and male preparation for war in time of peace, we shall not get the full bencfit out of these cruizers. There is a subject in connection with this inatter which was tonched upon by Licutenant Crutchles in the first part of his ji:per, which I think of grcat iwportance-I allucle to the question of communication and signalling during war between our cruizers and ships of the mercantile marine and between one merchant ship and another. I do not think that this question has been sufficiently considered at present. We heard last year that Lord Charles Beresford was about to bring forward some motion on the subject of signalling, but owing to the great demand on the time of the Housc of Commons, lie was unable to do so. Of course we all $\mathrm{kno \pi}$, all who are accustomed to the sca, that we can communicate with each other at present during the day time with flags, by the International Code-book, but there is no weans whaterer of communicating roL. XXXIII. 
at night. What does that mean? It means that during war-time one of these magnificent st camers that Lieutenant Crutchley has been talking about mas have some raluable information to gire to one of our cruizers, or a cruizer mas lare some rery important communication to make to lier, and neither can do it unlese they lower a boat or approach within liail, which is not almass an casy matter. Our positible future enemy may be kind enough to inrolse us in war during the summer when the days are long and the nights are short; but on the other hand we mas be dragged into a war in winter when, as we all know, on some dull dass, we could haro no communication with cach other between if o'clock onc afternoon and 7 o'clock the next morning. Jrany Oflicers in the mercantile marine hare thought shout this, and two or three gentlemen, consilering that our system in the Nary is too difficult and complicated, hare sent up some plans to the Boarl of Trade for night signalling, avd it lias been inj good fortune to hare to look into those plans and report upon them. I esanined them carefull 5 , and came to the conclusion $t_{12}$ they were certainly not so complete as our srstem, and were not more casy or more simple; but I rould not trust to iny own judgment only, and, therefore, put mesself in communication with the Flag.Captain at l'ortsmouth, and asked him to be bind cnough to giro me the opinion of his Signal Staff. I sent these proposals to him, saying, "P'lease put aside erers prejudice, and tell me if yon think they are workable, and if thes arc more simple and more casily learned than our own." IIe replicd that thes were workable, but that thes were not more suitable and not more casily learned than our orrn. So I came to the conclusion that if any system of niglit signalling is introducel, it must be the Morse system. When I say the Morse system, I mean the srstem wo use in the Nary, and which was first introduced by my fricnd Admiral Colomb. We know thit it is to him that wo are indebted for haring first introduced this flashing system of night signalling into the Niry. Now; I rish to point out to gentlemen of the mercantile marine the adrantage of this IYorse system. The only apparatus necessary is a lamp with a shutter or slide, which will cost, perhaps, 45 s., and a steam whistle, which is already fitted to ercry stcaucr. There is no code-book required, and signalling can be carried on under any circumstances, by night as mell as by day, and in fog as well as in clear xesther. It would require a traincd and qualifed signhlman in cach ship to rork it; but why should not our large etcamers carrs one qualificd eignalman? I do not for a moment supposu that niglit signalling could be carried on in our sailing ships or smaller steamers; but if the Admiralty and the lloard of Trade mould gire their sanction it might be introduced into our large mail steamers, such as those of the $P$. and $O$. line, and the magnifeent elips that cross the Atlantic. They wight, perhaps, if it were authorized, proride themselres with a lamp and allow one quarterwustar of cach ship to be traincl and requalify once a jear, as our Naral Kiserre men do. We might then liare a system of signalling between II Mer Majesty'. shij)s and the merebant scrrice, and in the merchant serriec itsulf between one slip and another. If this system were once introduced it would probsbly become popular. When I ras in the "Britannia" a fer years ago, we rather went in for the usc of the semaphore as well as the Jorse, and I was surprised to see the may the boss took to it. 1 uscd to sce them in the boats and in the cricket ficld making signals to one another with their arms. I beliere, that if this system were introduced into the mercantile untrine, it rould grow; young Oflicers rould learn it, and it would be taught on board the "Conway" and the "Worester." The Jlore srstem now holds the field, but if anyone can propose a better and simpler plan I hope he will do so.

Admiral lBors: I want to ask the lecturer one question with reference to the route betrecen Sicrra Leone and the Cape of Good Hope. He has not mentioned cither the islamts of $A$ scension or St. IIelens. St. Helena is a conling station rery fairly fortified, and perhaps the lecturer will presently gire us the reason why he bas omitted it. A curious circumstance happened to me only sesterday before sccing or licaring this paper. Captain Crutchley sajs history repeats itsclf; I sarr yesterday, in a shop window, an old print of two ships, which attracted $m y$ attention; it represented a British brig being captured by a French priratecr. Tla' prinatcer had lowered a boat; the brig was to windwarl; the brig put her helin up, ran elean into the privateer, carricd away her aftermast and sails, got clear, and 
wor she went and left the privateer to look ufter herself. That secms to une a condition of crents that might huppen again, especially when two or three ressels are together, and it bears on the paragraph in the paper in which Captain Crutchler points out that the stem of a merchant ship is nearls as formidable as that of a poul-of-kar, and that a flcet of merchent ships hare bcatcn off an cncmy beforc, and the inference is that stenm rould gire $n$ better chance now to do it again.

Captain Nore, R.N.: I wish to bring two important questions befne the rnecting. The subject of this lectire is the unprotected state of lititizh commerec at scu, and I preeume that what wo are to consider is how the commerce is to be best protected. I think the first thing we want to decide - as a great naral nation -is to what extent mut an armed merchant ship reccire the authority of the Corcrnment in order thet it may act as a kar-ship without infringing the maritimo luw by which priratecring is abolished. That must bo an exceediugly important question. Supproing, as Captain Crutchles obeerrez; that we did allow our increhant ships to carry armaments, is it posoible when they are abroad for them to receive authority enficient to enable them to act as ships of war? The next question is, to whit pennlty, if anr, a captirc merchant ship would be liable if her capture were resistcd br force of arms? I think that these tro questions are of great nntional inportance to England, and of sucli great importance that it is rery desirable that the Gorernment of the country should get a full and thorough understanding of them from other uations. I do not propose to go into the paper more fully. I appreciate and admire the way in which it has been put before us. It is most clear and concisc, and thoroughly to the point; in fact, it is one of the most raluable papers on naval subjects that we hare had in this Institution for a long time.

Captain Pexrose Fimzoensid, R.N.: Lieutenant Crutcliles inakes a sort of apology in the first paragraph of his paper for bringing forward the same subject on a third occasion. When I was coming down here, before I lad secn the paper, although I guessed what the nature of it was, I was making up my mind that I was going to pat bim on the back and thoroughly cncourage him in hamnering awar. If $\pi \mathrm{c}$ want $\mathrm{a}$ subject brought before the public it is no uso stating it once and then dropping it, and I was rather afraid when I heard the last paper that that was whiat he meant to do. We see the principle of reiteration adopted to enforce all sorts of fallacics and falsclioods, I might say, "in another place," if it is not actionnble, arid I do not sce why the eame principle should not be applied to truth, and to a patriotic course like this, until he insists upon his countrymen taking it up and looking at it. We hene the Irish question and rarious other fads hammered at until ve are sick of then, but here is a point which is rital to the existence of tho Empire, and what I say to Captain Crutchles is : do not.make this the lust time; go on until jou make them listen to you! There are sereral controrersial points, but really the general tenour of tho paper is so entirels to the point that one does not like referring to the points that one docs not entirely agree with. There is, lowercr, one point about the Nary. He eays: "All the discussions which hare taken place lately on the subject of our Nary have, as far as I liare ecen, been solely confined to the ability of our men-of-war to mect successfully those of our possible antagonists; the protection of the grcater part of the commerce of the world has not been touched upon." I am afraid people will get into the fallace of saying that lesides proriding a sulficient Nars to mect the enems, jou must liare prolection for your merchant commerce. Now if there is nobods to attack your commerec you do not want any one to defend it. If your Nary is sulfient to not onls crush the fighting silips and the regular cruizers, but also the auxiliary cruizers and similar ressels, that settles the question. If there is nuthing to attack you, jou do not want any protection. I refer to this point because it is the one logical argument of the opposition. I think lo made a most admirable allusion to the food supply when he said: "To comparo small things to grcat, what happens if snow clelays the orilinary traflic to the metropolis for threc days?" Ne know what happens. Distres of all sorts. That is a rerg concisc and admirable way of putting it, and I hope, whaterer other part of the paper is published, that they will publis $f_{1}$ that. I liad the honour sesterday of reading a paper rery cognate to this subject at the Taval Architects, and I quite agree with the lectures in saying that these large $\Delta$ tlamic cruizers which have been subsidized by the Admiralty will be wanted 
for their own trade routes, and we shall not be able to uge them as war cruizers at all. 'Ihey will bo required to use their enormous tonriage to carrs cargo, and to carry whaterer to us will be most raluable: it may bo coal, perhans, to different atations. I think it probably will bo conl, to fill up those unsupplied depots which Licutenant Crutchles so graphically brings before our minds, at the Cape of Good Hope and the Falkland Islands, nnd other places. I should think one of the best things to do would be to fill the "Firuria" up with conl and eend her to the Falkland Islands. It sounds a big order, but it rould secm to me to be the nost raluable thing to do with her, becausc for ehips of that tonnage to be simply used as protecting cruizers would appear to be an utter misapplication of their capabilitics. I think ho made a mistake in referring to the "Alabuma," because, ns far as I know; she only captured onc stcamcr, and we must look for the sailing ships being laid up. He says: "I hear it frequently said that in the crent of war our ships are to be transferred to a neutral flag." I nm rery glad he brought that point forward. It has bcen ect forth, I think, by no less authoritics than Iord Brassey and Mr. Forwood. It simpls means suicide; it would be the call of the rhole business: the British Empire would cease to crist. If you cut your throat, what more do jou want? Ir your trade is transferred to a neutral flag jou nust gire up busincss; it is strangulation, that is the end of all things. I hope the papers will put that down. Then with regard to the Declaration of Paris. It hiss been touched on sereral times in this theatre, but it las nerer been thrasbed out. I do not seo $\mathbf{3}$ r. Baden-Powell here to-das. I should like to hear him again on the subject. Admiral Colonb mentioned Lord Thring yesterday at the Naral Architects, und the mere mention of the name so frightened Lord Rarensworth that ho shut him up, and would not let him pursue the subject; the rery name of Lord Thring wiss suficient; he would not let him sas a rord about international law. It should be cleared up, though, one way or unother, before war breaks out. I remember on the last ocerasion Licu. tenant Crutcluley asked, in a pathetic manner, what was to become of him if he wirs found fighting, whether he was to be hanged, because, he said, is a matter of personal interest, he would like to lnow : and I dare saj he fecls it quite as much row. 'The doubtful point should be cleared up. I do not know whether Captain Crulchley can explain this sentence: "There has been a great falling off latels in the number of First Class Reserre men." I wonder if he can gire us any csplanation of that. I think it is a terrible pity if that be the case, and there must be some resson for it, snd I do thint that they ought to be encouraged to the rery fullest extent possible. With reference to Admiral Bouden Swith's obscrration on eignals, it scems to me to be the rery vital essence of the thing, and that his proposition is eninently prac. tical, to get one man who can work the semaphore or tho Jiorse code in cach ship, and then to allow the system to spread, and it would be, I belicre, as he eays, con: tagious; the men would soon pick it up, and $I$ hare no doubt if it rere once started in the merchant ecrrice, Captains paseing ench other on sea routes would signal to each other all gorts of interesting news, either with the whistle, the semaphiore, or the flashing light, as the case might be. If it were once started they nould use it, and the benefit of it when war came would bo simply inestimable, because they would be able to communicate direct with erers man-of-war they saw, and to giro them information which might be of rital importance to tho nation. A s5stem of signalling, so simple and jet so comprehensire, would form the strongest possiblo connecting link between the two Serrices, and its value in mar-time rould bo inestimable; but this, and all other organizations, wust bo completed in peace. time.

Renr-Admiral P. II. Cozoxn: I should like to add my nite to what Captain Fitzgerald has said, and to hope that Lieutenant Crutchles will not drop this subject, but will go on hammering away until he gets it right. We have to recollect that, after all, this question has been debated in our country for a comparatirely short time in our own dng. I think the Chaimm began it something like trentythree or tirenty-four yesrs ago. We bare becn more or less bammering at it crer since, and $I$ suppose in twenty-threc or twenty-four years more, if we continue hammering, the question will be understool. Ille whole of our naral position is usually misunderstood bs the ordinary Englisliman, and I might gire you a couple of ancelotes of what occurred to myscle recently as a proof of wiat I lase just 
aill. Last year as a part of the schene we rere then getting up, and which has produced Euch cxcellent results, I wrote to tho London Chaniber of Shipping and prod to them, "I do not think the shipowners as a rule understand the diticultics they will be placed in in war; if jou can get me an audience of shipowners, I shall bo happy as far as mJ humble powers go to help you to consider the question, which is nn important one." The nnswer I got was that an audience of ghiponners could not be got together to consider that questiou, the season was ngainst it. I waited until the season lad clianged, and I wroto again and said: " $A$ s tho pcason lins clianged, perliaps you could get an audience to consider the question of whether jou are going to retain jour ships in war-time or to lose them;" and the answer I got back was-and it was a rery remarkable answer, I think, I krep it carefully b5 me-that "I was a little mistalen as to the nature and offico of the Londoin Chamber of Shipping, that it did not cnly, as I secmed to suppose, represent the shipowners of IJondun, but that it consisted of delegates representing the shipowning body orer the wliole kinglow; nnd that, therefore, I wust sec that it was not the sort of body which ought, to be addressed on the subject I propesed." Nor, I will gire sou nnother anecdote. I read, as I suppose a good mans of us do, muel. of whist is said by the Press all orer the country on the subject of defenec, and nmongst the articles a fortnight ago or thereabouts was a long one from the "Scolsman" discussing some of these questions, using my namo and quoting ne as haring said certain things. The certain things I wis quoted as sasing were to my mind the greatest nonsense; and I was somewlat nettled at haring such nurds put into wy mouth. I Iowerer, I sat down and wrote a long, and as it was characterized, a rers "stormy" letter to the editor of the "Scotsman." I attached a piece of paper s.25ing I presumed it $\$ 2.23$ too long and too stormy for publication, but there it was. Ilowerer, the cditor put it in, and added a paragraph at the end of it. My letter explained some dillicult questions of narul policy, and amongst them the question we liare before us to-daj. The editor alded a parigraph at the end of it, sasing that lie had receired great punishment for the swall olrence of misappre. hending what I had said; that it was a rery stormy letter, and really after reading it carefully, he was quite unable to make out what it was the gallant Ollicer meant; "but," he eaid, " after a little time we will endearour to deal with this stormy Ietter." In a little time, in three or four days, there appeared a leading article, declaring that mr letter was the most lucid description of naral policy which they had erer read. That is to sas that iny words, you see, fell at first upon absolutelyblank minds; and Licutenant Crutchley must understand that his words when they go out to the general public in England fall at first upon absolutely blank minds, nad there is nothing to be dono that $I$ know of except to go hammering on I ham. ucring until thoso ininds get sufliciently receptire to understund what it is jou aro talking about. Captain Fitzgerald dealt, I think, almost sufficiently with une point of criticism that I picked up, that was the apparent supposition that war-ships as built at present were not prepared for the protection of our commerce; that they were prepared for contcnding with the ships of the enemy, but that in some way they were disconnected with the defence of commerce. Now, my opinion is as to the new programme of the Gorernment, that no person acquainted with what would hare to be done in war, who studies it, can doubt that that programme has been dramn up directly and distinctly in view of the protection of our commerce. The classification of the ships, the numbers of the ships of the different classes provided, were quite enough to conrince me at any rate that the protection of our conumerce has been in the mind of the Gorernment, and that the Gorernment hare at this present moment something approaching to regular plans which thes nerer liad before for the real protection of our commerce in war. I think Lieutenant Crutchley may consider that his former papers on this subject have lielped that, and that this paper will still further aesist it. The loss of the food supply is of coursc always touched upon, and we find in the country that question is again rers much mis. understood. Whey we epenk of "starration" in the technical sense, it is held that what is meant is absolute starration, an absolute stoppage of the food supply into this country. I an quite sure none of us mean anything of that sort. Whe know quite well that there is alwags such a thing as breuking blockade, and that it is almost inpossible to cut entirely off the crit and entrance of slips from any port. 
But this is what we do mean, that if it happens that our ships hare not frec passago orer the sen, tro things will come about: there will be a shorter supply of food in this country in consequence of a less quantity coming into it, and tic price will certainly rise far abore the natural lercl due to that circumstance. Nlso, this is quite certain, that at the same timo as you lose your full eupply of foot you will also losc rour full supply of raw instcrial. How uro jou situated uncler those circumstances? Food has run up in price, labour has necessarils gone down in price. Aro we wrong when we used the word "starration" to imply that condition of things? I do not think we are. I rery much agree with what the lecturer said as to tho doubt that esists in our wiuds whether, cren in the casc of these subsidized steamers, it will be possible to remore them from their ordinary routes. I greatlydoubt it. I think that they will hare to bo utilized in some nay orer their ordinary routes. As to dealing with capturcd ressels, I think that the lecturer rightls classifies the different met lools of dealing with them; and then I think we may go back to history to see pretty well what would happen. The old priratecr al ways brought out a number of spare cress on purpose to put them on board the captured ressels; and although we are not allowed to usc the word "privatece" now, although the ship which will do the same or worse work as the priratecr did will not be called a "prirnteer," Jet I hare no doubt whaterer that this commissioned ship will take with her a number of spare crews. And then you must recollect that if one of these small ressels malies a capture of a big ship, such as tho lecturer has spoken of, that will be suficicut for her purposes; that one big prize will mark the success of her cruize; sho will bo ready to go back into port argin after haring madc that grcat capture, and I conccire that generally speaking the practice must be to put crews into the steamers when captured, and to endearour to get them back into port; not only becaluse of the ralue that is sared to the captors, bul also because crery stcamer captured from us which goes into an cuems's port mag come out of that port commissioned as a man-of-mar and raider for the purpose of adding to the mischicrous flect which is troubling re. I will now state what I had not the -opportunity of stating yesterday at the Niral Architects. Lord Thring in this theatre, a couple of years ngo, in discussing an analogous paper to this, distinctly stid that thero was no question vliaterer about the right of a merchant ship to defend herself; that a merchant ship hind a right to defend hersclf against capture by an cncmy, precisely similar to that which anf Englishman has to defend himself against a garotter or burghar. Of course I quite agreo with Captain Fitzgerald and Captain Focl that it is most important that this very elementary question should be laid down as ecttled by authority. I must confirm Captain Fitzocrald also about the "Alabama." I think if more than one steamer' was captured by the "Alabama" there were rery few. "This much is certain, the "Alabama" made nearly all her captures not under steam but under eail, and it was beculuso she made then under sail that she was able to hare such a long life of it. Other Confederate shipz which tried to make captures under stcam soon expended their coal, and then disappeared into ports from which thes never canc out again. As to the transfer of the flag, we had that at the Naral Arelitects only jesterday. IIere the question is raiscd again. It is quite forgotten, as the lecturer has so abls put it formard, that thero are not flags cnough to hold our ships, not antions cnough to take them up. If you look into the law of transfer of the flag, as laid down by the international lawyers, jou fird that the conditions are vers diflicult to get orer on the part of our slipowners, who think so lightly about the transfer of the fling. What it menns is that ther are going to sell their ships at a sacrifice, and never get them back again. There is one point which 1 beliere is quite certain as regards france, which is the country after ali that we hare nost to think about. France I hare very good reason to beliere is almitted by international Iaw to bo able to sustuin the position that she will not recognize any change of flig whicls takes place after tho declaration of war. So where are jou? $I$, in common with prerious speakers, would like to bnow more as to how it is, and to what extent, the Naral Reserse is said to be falling off. I hare the highest possible opinion of the Naral Rescrre, and I am sure ke rightily rely upon their help in war-time. I should like to see their numbers greatly increased, and I think it is quite possible that a second-class reserre mar come out of the failure of our attempt to worl the defence of our shores through the roluntecrs. I take it that it is rers likels that through 
yome sccond-class reserre that may be better effected. Perhaps I may bo cxcused for adding a word upon the subjest of signalling, which has been mentioucd. I roukl like it to go forth through the Press that $I$ am pretty sure that we sliould hare had the flashing system in common use in the mercantile nariue some-time apo, had it not been for the dircet interposition of the Board of Trade. Nearly the wliole of the steamship companics of Liverpool at the time when the distress signals were clianged, and when diliculty in the mercantile marine arose in conszquencethe greater part of the steam shipping companics in Lircrpool, on my moring, applied to tho Board of Trade to be allowed to use that system to distinguish themselres at night, and to communicate amongst themselres, and the Board of Trade gare a distinct refusal.

Admiral Bowdex Syitur The Board of Trado are now willing that thes should do so.

Admiral Cotosis: I am rers glad to hear it. It oumlht to be known that we could hare lad the thing moving now, bad it not becn for their direct interposition. I was unable to ascertain the reasuis for this forbilding, for it was a direct forbidding of the companics to usc it. But after some months when I mas beaten, and liad lost, as it were, interest in tho subject, perwission was giren. But the thing Lad passerl, and I could take no further steps about it. I think that Admiral Bowden Smith is perfeelly right in going for what is called the Jrorse system. The Yorso systcm is simply the application of the flashing system of signals with the Yorse alphabet instend of the figure signs which we use in the Nary.

Admiral Bowdex Sirtul : Did usc.

ddmiral Corous: Do use with tho signal.books. It is a different systen of notation, that is all that it really comes to. The fact that there is a difference of notation apart from the Morsc sjstem rested first on the form of our signal-books in the Disry, and sccoudls upon the immense difliculty of getting the Nars at that day -twenty-cight years aro-to understand what it lat got before it. It would hare been inpossible then to hare indued the Nars to adopt the Jorse notation rith the fashing sfstem, it was hard enongh to get them to adopt a notation which was verg much more simple. But time has gone on, and for ten Jears past I hare urged that the time was come for abolishing the original system of notation in llashin: signals both by day and night, and fully adopting the Jorsc notation. Ind tho signal-book in tho nereantilo marine lends itself directly to this, and almost compels you to adopt the Jlorse notation. I fecl quite sure from what I hear that some of the larger steamship companies are almost on the point of moring for themselres in this matter, and that the vers slight encouragement which thes are now getting, and which I hope will be continued, will induce them to adopt it. I quite agres that as soon as the thing is sturted, it really is so simple and easy, it will grow. The fact that the Morse notation is used for rearly all telegraplic uiessages and all teleyraph work wiakes it all the more cass to establish in the mercantile marine, and its already being established in the Nary gires a further adrantage to it. In time of war the fact of the mercantilo marine being able to communicate with one another and with the sbore, for that is most important, at considerable distances by night and by day, and also in fog, all of which are to be done by the flashing system, is one the importauce of which cannot be eraggerated. I am vers much obliged to the members for the altention thes haro giren to me.

Sir J. C. J. IIAr, Bart., K.C.B.: Thi3 rers excellent paper which Captain Crutchles has put before us requires rery little explanation to make it clear to any one of us, but 1 am particularly ansious that in his reply he should male it apparent to thosc outside this theatre, as it is entirels apparent to those within it, that these suggested lines are mercly a very emall fraction of the lincs which would hare to be protected in caso of war: that, as a matter of fact, thes are but tro lines out of at least six important lines which it rould be necessary for the Nary to protcet, or on which it would be necessary that merchant stcamers should be arwed. Captain Crutchles should also make it apparent to thoso who mas read the paper and may not hare heard, or ecen the map which ho bas produced, that the illustration giren of thesc routes depends upon the closing of the Sucz Canal, ohich Le anticipates may possibly occur, and I trust it may occur, for it would be greatly to our adrantage if the Sucz Cinal were blocled in war. In such an erent, 2 large proportion 
of our commerce would come upon these routes. But with regard to these routes I Bhould like to say this: Captain Crutchley appears to asoume that the Rirer Plate, Rio Janciro, Bahia, and Pcrnambuco, would be open to our commerce. My impres. sion is, Brazil being neutral, and looking to recent interpretations of contraband of war, they would not be 80 open, and the commerce coming through the Straits of Magcllan from Australasin or the Pacific would here no place to call. Sandy would be closed in the Straits of MIngellan; the Falkland Islands aro not protected; Berkeley Sound is not in the sclieme of these harbours to bo protected and protected conling stations. It nould therefore be ncccssary, in $\mathrm{my}$ opinion, for that route which Captain Crutchley suggcsted, along the cast const of Soutl $\Delta$ merica, to be direrted either to the Cape or to St. Ifelena. The Cape is about to bo pretts well protected. St. Helena, which bss been mentioned as having been omitted, but which, no doubt, Captain Crutchley will refer to in bis reply, may bo rendered impregnable, and mas be looked upon as a rendezrous, not only for ressels passing round tho Cape, but for those direrted through the Straits of Mngellan away from the coast of Irazil to the protected station 3 on tho routo homeward. Sierra Leone no doubt is in proccss of being mado rery strong; I believe the fortifications are planned, and eone of them are commenced, and tlie guns are about to be made. But it would not be a rery pleasant place for all the liects to rendezrous. Good though the harbour is, as we know, the climate is not the most salubrious. It secma to me that the route which is described on that clart is sot a roulc which could be adopted, in consequence of the abence of coal supply and of the fact that there is no pretence whaterer to fortify, protect, or hold the Falkland Islands. There is nnother most ueful coaling station, but it is not to be protected. I allude to Ascension, a most raluablo place, which, of course, inay get into the hands of a priratecr or a foreign Power with great facility. With regard to the question of arned merchant ships, there secms to be a general belief that these merchant ships are rery fust, that they are fuster than anj possiblo cnems rho would presume to interfere with them, and that it would be a case of bolting all over the world, and that there is to be neither conroy nor protection neccssary. I recognize the great speed of these resels, and I myself would be in farour of conross under numerous merchant ships, partially armed in the manner suggested by Capitain Crutchles, guarded and protected by men-of-war capable of steaming as fast as thes. But that appears not to be a plan which commends itself generally to the public mind, and I fear wo shall loso many single sbips unless some neans be adopted to gire the mercluant shipg that protection which, in my opinion, I beliere theJ aro fairly catilled to, use to defend themsclres against all eril-doers. The question is, whero are you to get the gunz? Captain Crutchley, perlaps, can tell us. I remenber when, more than trenty years ago, it was intended for the first timo that morchant ships should be taten up for the assistance of the Narg in war-time; it was then proposed that a certain number of gums should be made and put in stock for the purpose of arming them. Many merchant ships hare been fited for the purpose, but the guns are not jet made, and it has been twenty-two or tirents-three sears, I think, since that order was giren. The prirateers which we hare to fear, I think, are not entircls the priratecrs of the Powers with whom we might expect to be at war. I believe there are other enterprising nations who would lend themsclres to that parti. cularbusinces, whu would require flags which might be raluable to them, and haring got those Aags there are other nations which hare not themselres entered into that mest mretched and disagrecable Treat5 of Brusiels, who would perhaps rather go to war than not defend their subjects if they were successful in the art of priratecring. I should bo glad to bear from Captain Crutchles, like many of my brother Oticers, if he could etate why it is that the First Class riaral Reserro is no longer so populas as it was. Is it that the regulations under which the men nse aceepted are too stringent and higher qualifications sre expected, or is it that trade being better thes find enplosment elsewherc, and do not care for the fec which they get to bind themselres to this country?

Admiral Sir E. Oxysiser: As a naral Officer it is most gratifying to hear from so competeat an authority as Captain Crutchles on matlers concerning the mercan. tile marine the ricws which are cntertained by that community on the rery important points contained in this raluable paper. I am much struck rith one proposal 
regarding the armament of great ocean stcamers, namels, that thes might bo fitted with the power of rumning an cnems. I think this is a rers practical and simple suggestion, and one which could be carricd out in the construction of these splendicl scascls without entailing anj scrious cxpenso on our mational compunics, and would inrolre no interference with the arrangements and qualifications of these resucls; as thes are driren with such a prodigious velocity thes mould then be prorided with as formidable weapon of destruction upon warships of inferior speed. As an old signal Onicer I nm plesed to liear that the means of signalling bJ night between the Lary and mercantile ressels is bcing organized under the auspices of such a rery competcht and erperienced Officer as Kear-Adiniral Bowden Spith.

Ciptain Centrs, R.N.: I might suggest, with respect to the relicf of thesc captured ressels, or what is to be done with thew, there is another was of redceming them. Tlie "Alabamn" relcased sereral of her captured ressels upon their Captaing giring bonde, and I belicre that thoso bonds werc all honourably met. That nould be in grent f:trour, I think, with the crews of the ships. I do not bnow whether it would be legal or politic on board a man-of-mar or not. We are often compared to a fortress in war-tine, olut up, and liable to be cut of from our supplies. 1 I nerer lacard it suegested anjwhero that we ehould liare three month' corn stored in tho country ; in Gibraltar and Yralta they hare a year's store of grain. It might bo xuet in this was, by the Gorcrnment giring a bounts to merchants or paring them some moves for becping so mucl corn stored. Cuptain Crutchles eaid Listors repeats itsclf. Latcly I read tho histors of the old East Inclin Company's scricice. Whenerer our ressels were in a minority our scamen and merehants always suffered, and wo lost the Moluccue in conscquence; and when Olirer Cromwell took matters into his hand he made the Dutch pay 250,000 l. compensation for the mal. treatment of our merchants and men. With respect to coal, Captain Crutchles: said our ressels nuight use IRio Janciro. I belicre, from what I can learn of the matter of coal, if an English man-of-war puts into a neutral port, that neutral port will onlr supply them with coul to go to their nert coaling station, and they cannot use that coil for war purposes, unless in self-defence. I belicre that is correct. There is another point that Captain Crutchly has not touched upon, and that is the route frou the Falblands' to Fancourer. Fancourer is getting a rers important place, and I suggested to one of the late Commanders-in.Chief on that station that it would mect the approbation of his countrjmen if we could get one of the Galapagos Islands, and I belicre Chatham Island is a rers suitable point, being equidistant betreen Falkland Island and Fancourer, in a straight line, about 7,000 wiles. 'That group belongs to Ecuador. Ecuador is not a rery rich country, and 50,000l. might buy one of thoso islands, and any ressel rendezrousing there-for instance, if jou had no coaling station you could put your slips in between the islands, and a man-ofrar at cither cnd would prerent any ship attacking then. I did not understand exactly what Captain Crutchley meant by arwing werchant ships. I presumo tho Gorernment would ncrer put arms on board mercliant ships unless thes thought they were authorized to usc them.

Notr.--Albemarle Islond is 4,700 feet high : a good look-out could be kept from (lere; the islands are in a rery commanding position.

The Cransis (Sir J. Colomb) : Before nshing the lecturer to reply to the questions that hare been asked, I mas be permitted to add to the general cliorns of approrai cxpressed, not only of the paper but of the persistency of the cfforts of the lecturer. It has becn pointed out that tho people of lingland are, in apito of this Institulion, in spitc of nuns able roices that hare becn raised, still blind and deaf to the real grarity of this whole question. I think this Institution is also to be especially con-

1 Page 33S, Whittaker:-

Talue of wheat and flour imported for 1SS7.... $£ 31,365,802$

Talue of three months' supply ........... T,S\$1,450

5 per cent. interest .................. 392,070

compensation for money dormant the merchants would receire. I think it rould, if war mere libely to occur, be wiso to lare sis months' stored; it would not amount to $\frac{1}{2} d$. in the pound income tar. $\rightarrow$ J. D. C. 
gratulatel that an Officer of the mercantile marinc of practical knowledge, of practical cxperience, and at this moment closely and absolutely connected with it, cones forward to give us his ricks upon this most important question. I think the matter would hare been rery much better adranced Jears ago, if the mercantile marine had had more Ofiecrs who not ouly thought of these things but were good cnough to come and give the naval Offecrs and the experts who meet bere, an opportunity of hearing their riers and of haring that joint consultation which is necessary for the organization and protection of the commerce of the Eupire. I take the grand lesson brought before us in this paper to be, in the first place, that our huge conmerce is almost ut the mercy, 28 far as any means of defending itself gocs, of improrised riiders under other $\mathbb{A}_{3} g s$, and that it brings before us this great fact, that practically nothing has been done with regard to the real orgenization of the means it offers for assisting the Rojal Nary by its own protection to a certoin cstent, and that nothing whaterer has been done by this country either to suggest a scheme or to work it out. I do trust and hope that this paper, secing the mariced approral it has met on all hands, will, as my brother said, lave a direct bearing and influence upon the Admiralts, and 1 hope that one of the matters that it will make the Admiralt $y$ reconsider is their present programme of subsidizing the best of the mail steamers for the purpose of remoring them off the lincs in time of war. I took a rery st rong line in t!iat matter, because I uored the rejection of the first rote, having ascert:ined in the House that the Adiniralty did inteud to remore then from the lines in war; I mored the rejection of the rote, and stated my reasons for considcring thist the plan was bad in theory aul would turn out bad in practice. And I miglit mention, in order to emphasize what tho lecturer has said, that there is another point to be considered in remoring tlicso stcumers from off these lines. Our commerce may be grouped into two clasecs-the stcum commerce and tho sailing comnerce. I do not spcak of it, for I think ne are all tolewabls agrecl upon this, that war uncans the cetinction of the sailing commerce, aud therefore it, is only ncecssars, as practicul uacn looking at it frou a proctical point of rier, to consider tho steam commerec. Well, now that mas be grouped into two great classes, the regular liners, trading regularls between fised points, and wliat maj be called the all-round tradc, and of course there are difliculties connected with organization for protection of the all-round trade that do not present themselres in the case of tho regular lines. Now the most important lines are those lines that connect our orn Empire, and those are the lines that, unless jou are prepared to lose that Empire, must be maintained, and not mercly maintained by the horal Nury but lle actual traflie between theso different parts of the Fimpire znust bo kept going. What happens when jou remore the best ships? Take India, take the $P$. and $O$.: the proposition is to take the best of the $1^{3}$. and $O$. ships off the lines on the outbreak of war, and to pay them in peace to enable sou to do so. When war comes, when carrying out that policy of remoral off the line, it will be a matter of the most rital importance that sour dircet communication should be leppt up, and both as regards the actual ralue of the trade and the rapidity of communication that will be a pressing necessity in war. What are you going to do? You are going to take the best ships off the line, those ships tliat posecss the quality that gires the greatest safety to a merclant stcumer, that is her specd. You are going to tako the fastest ehips off the line on purpose that when the hour of peril comes the remainder of the line shall be in extreme danger. Ind you do more than that: jou send up the price of freight on that line, because you at once raise the insurances. Fon are defeating your own object, and for this reason, you take the best ships off the line: jou force your mails, your passengers, perliaps your troops, jour raluable cargoes, rour specic, erersthing into slower ships, and in proportion-I think it is quite obrious-to the speed and porrer of the merchant steamer, to will be the insurance risk. 'Therefore I do trust and hope that coming from a man of practical experience: like the lecturer, being backed up by the naral Oflicers as he has been on that point in this theatre, the paper to which wo hare listencd to-day will certainly put a nail in the coftin of a policy which we cannot look at without dismas. "To giro you another reason. 'The P'and O. lines to India, the "Union" aud the "Castle" lines to the Cape, the New Zealand lines, all these are subsidized for beeping up the interual postal communications of the Empirc. How has it come about thit they 
are 80 good and hare such magnifecnt ship3? It has come about in this nay, that the necessities of your position in peace demand it. They haro been subsidized and asisted by mail contracts. These mail contracts-take the casc of the Cape or India of 1 uetralia, whicherer case you like-these subsidies are joint subsidies made up of contributions from the mother country and your Colonies and possrssions, which thes connect by their operations of trade. And I am quite certain of this, that, when war breaks out, thougl the Admiralty mas hare paid during peace for the right of taking them of the lines in war, the dunisalts would not be able to do it for this reason, it would be breaking faith with your own Colonies and dependencies at the hour when thes moot require their mails, passengers, and trade eprices best performed, and you propose te cripple them all by renoring from their lines their fast ressels. What are jou then to do instead? I agree with what is indicated in this paper. Fou unust deal with the nercantile suarine in groups. The orcanization of jour mercantile marine for the defence of your Imperial routes, connecting jour own Fmpire, must, I believe, be jour first care. Fou must deal witl compunies as sou now deal mith the indiviclual ships. The "Cistle" or the $P$. and $O$. and all tho other companies must understand tluat when ther get a postal contrict it means they are to run in peace ond in war, and further it menns that it is the busincss and duty of the Admiralty so to promote and foster the growth of organized fighting eflicienes of the rarious companies' fleets as far as can be done without undue interference with trading requireusents, that thes shall be as it were an armed flect in war, carrying on the comumnications of the Empire, and sleo running down the lines of the all-round trade by sometimes perhaps a litele diversion from the ordinary route. That appiars to me to be the true polier, and the policy which I hope, by the persistent effort 3 of the lecturer anil such specehes as we have heard to-day, may at last be forced upon the mind of the Gorerument. The lecturer has said, "I cannot conceire any one calmly contemplating the transfer of our ship: to forcigners." I will emphasize what my brother said with regord to the apatlyy of shiponncrs. I heard tho Vice-Chairman of this rery Union Shipping Company in the House, within the' last few dags, ealmly indicating to the House that it was preposterous and absurd to supnose that you could protect your commerce in war. Fo doubt, in his ignorance, he beliered that, and has quoted the "Alabama." Well now, I think that people quote the history and the results of the cruize of the "Alabana" without really haring thoronghly studicd the question. I think the lesson to be learnt from the carcer of the "dlabama" and the Aucrican War is a rers remarbable one, and a lesson we may well take to heart-the mant of apprecistion of the American Gorcrnment at the outbreak of war, of Hhat naral war meant. Fou nay remember that on the outbreak they called together a sort of council of eminent men of Fen Fork to ask mhat should be done for scciring the blockade of tho Southern States, and this council suggested that if they had thirty ships they could blockade the whole coast of the South. In a reis short time, howerer, it was found they could hardly; with inprorised war ressels, do it will 600 . But the other lesson which is to be learnt by tho "Alabama" is simply the lesson which is largely indicated by that rery cliart of the lecturer's, and those who hare read and studied the cruize of the "Mlabama" will find that her success, as Captain Semmes himself points out in his book, was due to the fact that the $\mathrm{Nary}$ l)epartzent of the United States bnew nothing at all about their business. I slould like to quote a passage from his orn journal. He writes about the despatel oi vessels to catch him, and ho sars, writing in his joumal at $8 \mathrm{ca}$ in the West Indics, "The enewy has dono us the honour to send in pursuit of us the 'Powhattan,' tho 'Ningara,' the 'Iroquois,' the 'Keystone,' and the 'San Jacinto.' Sot one of these ressels ever cauglit her, although there were sereral cthers looting for her ;" and then he explains the reason : "Tlie Jons passage being the regular track of the U.S. commerce, it was looked upon as almost a certainty that at least one cruizcr would be stationed for its protection." But there was none. Anel then Captain Scmues, writing just off Yemambuco, sajs: "Where can all the enewy's cruizers be, that the important passages we hare lately passed through are all left unguarded ?" And then lie finishes of : "The sea lias its highways and brewars as well as tho land. - . If Mr. Wells (Secretary of the Fars Department) had stationed a hearier and fuster ship-and ho had a number of both heavier and faster 
ehips-at the crossing of the 30th parallel, another at or near the Fiquator, a littlo to the eastward of Yernando de Noronhe, and a third off Bahia, he must hare driven mo off or greitly crippled mo in my morements. I fow ships on the other chief highwass, and his commerce rould hare been pretty well protected. But the old gentleman does not secm to hare thought of stationing a ship anywhere." The whole lesson of the "Alrbana" is this, to excrcise our intelligence and our forethought to recognize the real work you would have to do in war, to utilize our resources in erers was, and proceed in the manner and direction indieated by this paper; and as to our commerce being swept from the $5 \mathrm{ka}$, I for one do not beliere it, unless we are unworthy of the trust imposed upon us.

Lieutenant Cretcnem : 'Ilwere are one or two points upon which question 3 hare becn asked unc. The first one is that matter of night signals between resscls at ses. I do not think, mysclf, there would be the smallest dificulty in introducing them in:o the merchant service, and I fecl consinced it could bo donc with rery little trouble, but at the sane tine, if thesc Mlorse signals are introduced it would be as well for resscls on the long routes to hare paper sealed books, for which I asked in my last paper. There would be no more trouble in using them in war-time than in using the ordiuars books. MIs rcason for not mentioning St. IIelean as a coaling station was because, if you look at the distance between Cape Horn and St. Helens, there is a rel's great difliculty-the difficulty as betwecn St. Helenz and Rio and the Falklands. Yessels couning from Australia would hare too far to stcam, and that was the resson I omitted it. Of course it would te of use for resscls between Table Bay and Sierra Lcone, but I do not seo that it would be practical to male one conroy if St. Helens were made a rendezrous, in other words, for the ships to come from dustralia viä Capo Iorn to St. Uelenn, and join the Cape ships there; it would be tou far to stcam. Captain Fitzgerald supposcs that if our Niars is incre:tsed it will be able to cope with all the enems's war-ships, eo that there will be none left to harry our commerce. If other nations are to be bourd by tho Ireaty of l'aris with ourselves, and unable to carry guns and unable to fit out their merchant ships, there vould be no neccsity for us to do so, but it appears to be nssumed, aud I think we are fair in assuming, that forcign nations, France, for instance, would not consider herself hampered by the Treaty of Paris, und thes rould undoubtedly fit out their faster ressels with guns in ouch a manner as that they could harass and catch ours.

Captain Fitzaneard : Are we to understand we are to be bound by the Treaty and others not? I cannot accept that.

Lieutenant Crutculex: The French mail steamers undoubtedly bare privileges denied to our own. 'Thes claim the right, in the Australian ports, of men-of-war, and thes hare it, so that when I ask that these mail steaners of ours should be armed and put into a condition of defence, as I lare said sereral times, it is not any question of their contending as men-of-war, but simply putting thern into a condition to enable them to meet ressels of their own class on equal terms, and I think it rers hard to see that there should be a unc-sided game, and that these ressels should hare privileges which we hare not.

Captain Fitzae basd : Does not jour R.JK.R. gire you the same authority to fight as a Frenchman?

Lieutenant Cnctcricer: I think it does; I do not think there is anj doubt of it, but the fact remains that these Mesengeries steamers have rights which are denied to us. As to the falling-off of first-cless men of the Keserre, I am unable to gire any reason for it, but that it is so I lare on very good authority. I think if ame effort were made to encourago the Reserve, tlie thing would bo altered. Seamen hare detcriorated in many respects and aro not as well qualified to maintain their rating as thes were; they cannot do the old tricks of sniloring in the war they were dowe twenty years ago, they hare not the training, but they are as gond Finglishmen now, and as good for the work they hare to do, as crer they were. I bare heard people eas there is a prejudice agninst carrying Englishuen in their elips, and thes prefer foreigners. I can on!r say, from what I hare secn of Englishmen, I hare sailed with English crews under the Hlue Eisign for the last twenty Jears, I hate had no trouble wortle spenking of: thes hare alwags done thcir work well. Sir Jolin IIny spoke as to where the guns wero to come from that were to be supplied 
to these ressels. In the sear 1863 there nas a circular iesucd by the Admiralty that they wero prepared to supply guns to ressels of a certain size if the onners would guarantec to build magazines and keep things in proper order. I tried to work on that end to sce if thero was anjthing to be got out of it, but erers one has forgotten all aboul it. But if thes thought it was necesonry to do it at that time, I think it may be found necessary to do it now, and I think from four to six quick. fring guns should be supplied and put in resscls on these long routes. In concli. cion, I hare onls to thank you for sour rers kind reception of my paper.

The CHairuse: I ain sure sou will all hicartily agree that the lecturer descrres a most licarty rote of thanks. 